\title{
Coarse woody debris and wood-colonizing fungi differences between a reserve stand and a managed forest in the Taborz region of Poland
}

\author{
Sławomir Piętka ${ }^{1} \cdot$ Agata Sotnik $^{2} \cdot$ Marta Damszel $^{3} \cdot$ Zbigniew Sierota $^{1}$
}

Received: 10 August 2017/Accepted: 7 December 2017/Published online: 13 March 2018

(C) The Author(s) 2018. This article is an open access publication

\begin{abstract}
The aim of this research was to evaluate the amount of woody debris $\left(\mathrm{m}^{3} / \mathrm{ha}\right)$ on the forest floor and the associated wood-colonizing fungi. The study was performed in the Taborz region, known for its Scots pine provenance experiments, against the background of a recently launched Polish legislation to protect the biodiversity on the forest floor in managed (harvested) stands. We investigated a managed stand (136-years-old) and the reserve stand 'Sosna Taborska' (261-years-old). In the reserve stand, the mean volume of woody debris was six times higher than in the managed forests, i.e. 65 versus $11 \mathrm{~m}^{3} / \mathrm{ha}$. In addition, in the reserve stand, the number of fungi taxa colonizing the dead wood was larger than in the managed stands, with a higher number of fruitbodies. Total fungal richness was higher in the reserve than in the managed stand, i.e. 28 versus 12 species. The dominant taxa at both sites were Fomitopsis pinicola and Fomes
\end{abstract}

The online version is available at http://www.springerlink.com.

Corresponding editor: Tao $\mathrm{Xu}$.

Project funding: The project was supported by statutory funds No. 15/20.610.028-300 from the Faculty of Environmental Management and Agriculture of the University of Warmia and Mazury in Olsztyn.

Zbigniew Sierota

zbigniew.sierota@uwm.edu.pl

1 Department of Forestry and Forest Ecology, Warmia and Mazury University in Olsztyn, Pl. Łódzki 2, 10-727 Olsztyn, Poland

2 Miłomłyn Forest District, Nadleśna 9, 14-140 Miłomłyn, Poland

3 Department of Entomology, Phytopathology and Molecular Diagnostics, Warmia and Mazury University in Olsztyn, Prawocheńskiego 17, 10-721 Olsztyn, Poland fomentarius, although some taxa were only found in the reserve (e.g., Stereum hirsutum). The volume of woody debris as well as the diversity of fungi in the managed stand were lower than in the reserve, albeit greater than in other Scots pine stands in Poland. These results testify to the gains in biodiversity yielded by the management conservation management approach at the reserve stand.

Keywords Coarse woody debris · Fungi - Managed (harvested) stands $\cdot$ Reserve $\cdot$ Sosna Taborska Reserve Forest · Indices

\section{Introduction}

In managed (harvested) forests in Poland, until about 30 years ago, woody debris left on the forest floor was regarded as a source of harmful insects and pathogens. However, according to the new forest policy and the multifunctionality model of forest management based on ecological aspects (Forest Act 1991; Polityka 1997) as well as in combination with the Forest Stewardship Council (FSC) rules, coarse woody debris (CWD) is regarded as an added value in forest management and an important contributor to greater levels of biodiversity (Szewczyk and Szwagrzyk 1996; Pasierbek et al. 2007; Kruk and Kornatowska 2014).

Dead wood is defined as wood of stumps and different parts of dead trees standing (e.g., snags) or lying (fallen $\operatorname{logs}$ ) on the forest floor, decayed by fungi and inhabited by other organisms (Harmon et al. 1986; Bobiec 2002). The wood of dead trees is particularly visible in natural forests and reserves, where trees are left to decay naturally (Sturtevant et al. 1997; Motta et al. 2006).

Skwarek and Bijak (2015) reported that the average volume of dead wood in Poland forests was $1.9-14.4 \mathrm{~m}^{3} / \mathrm{ha}$. In 
state forests, the total volume was $2-5 \mathrm{~m}^{3} / \mathrm{ha}$, while in 23 national parks, the total volume averaged $37.4 \mathrm{~m}^{3} / \mathrm{ha}$ (personal communication). In 2004, the amount of dead wood was $0.6 \mathrm{~m}^{3} / \mathrm{ha}$ in managed stands in Austria, $1-3 \mathrm{~m}^{3} / \mathrm{ha}$ in Germany and France, and $12 \mathrm{~m}^{3} / \mathrm{ha}$ in Luxemburg and Switzerland (Dudley and Vallauri 2004). Lofroth (1998) reported that in sub-boreal coniferous stands in Canada, the amount of dead wood ranged from 44 to $268 \mathrm{~m}^{2} / \mathrm{ha}$. The issue of woody debris in forest stands is highly relevant, especially against the background of discussions about the amount and size of wood that should remain in managed forests and be subjected to natural decomposition (Bobiec 2002; Heilmann-Clausen and Christensen 2004). In this context, this study compared the volume of dead wood on the floor and the wood-colonizing fungi between old, managed stands and reserves within the same provenance area.

The main objectives of this study were: (1) to evaluate the amount of dead wood on the forest floor of a managed, old Taborska Scots pine stand and in a reserve forest; (2) to quantify the dispersion of dead wood by sampling line transects; and (3) to quantify the diversity of fungal species colonizing the woody debris. We hypothesized that new ecological approaches in harvesting stands would have a positive effect on the mass of woody debris and on the diversity and abundance of fungal species colonizing the debris. The goal of our study was to contribute to the improvement in the management of harvested stands, especially in terms of the amounts of woody debris left on the forest floor in intensively managed forests.

\section{Materials and methods}

\section{Research area}

One study site was an old stand of Scots pine provenance, the "Sosna Taborska" (Taborz, 19 ${ }^{\circ} 59^{\prime}$ E, 53 $47^{\prime}$ N, Poland), located in the Miłomłyn Forest District in the $84^{\text {th }}$ East Baltic-Byelorussian lowlands (Mazurskie Lakeland Macroregion) in the humid continental region (Kondracki 2002). Most trees in this site were older than 120 years (Scots pine harvesting age in Miłomłyn FD), and the entire reserve forest covered an area of 95.32 hectares. It was established in 1957 to protect the old Scots pine ecotype that was reported to have high genetic and natural values. The other site was located in the Śródjezierze Forest Range, in the same forest district (Fig. 1).

At each site, we selected two compartments; one was characterized by pine + beech, oak, spruce, and hornbeam $(\mathrm{P}-\mathrm{BOSH})$ and the other by pine + beech and oak (P-BO). In the Sosna Taborska reserve, compartment P-BOSH (93c) consisted of 261-year-old pine together with 121-year-old beech, oak, and spruce, and 81-year-old hornbeam, while compartment P-BO (94a) consisted of 261-year-old Scots pine together with 20-year-old beech and 121-year-old oak and beech. In the managed (harvested) stand in the Śródjezierze FR, the respective compartments P-BOSH (203b) and P-BO (213d) supported 136-year-old Scots pine.

\section{Assessment of dead wood and mycobiota}

We adopted the Line Intersect Sampling (LIS) method to assess the amount of woody debris on clear-cut areas (Marshall et al. 2000; Nemec and Davis 2002; Motta et al. 2006; Böhl and Brändli 2007). In September and October 2016, we randomly sampled three parallel transects of $60 \mathrm{~m}$ each in each compartment; each transect was separated from others by a distance of $30 \mathrm{~m}$ (Fig. 2).

We used two algorithms; one to assess the volume and one to assess the number of pieces of dead wood per 1 ha (Van Wagner 1968; Marshall et al. 2000; Böhl and Brändli 2007). Coarse woody debris pieces (CWD) on the forest floor were measured when the diameter was $\geq 2.5 \mathrm{~cm}$ at the crossing point of the transect line. The fruitbodies of the fungi on the CWD were counted and identified with reference to Breitenbach and Kränzlin (1984, 1986, 1991, 1995, 2000), Ludwig (2007) and Kränzlin (2005).

As the data for wood volume and log number, diameter, and length were not normally distributed, despite the log transformation, we used nonparametric tests for all data. We used the Mann-Whitney test for comparisons of two independent groups. The Kruskal-Wallis test (Dunn-Bonferroni post hoc test) was used for the analysis of variance. Statistical analyses were performed using the PQStat statistical package (PQStat 1.6.4).

The effect of woody debris on species richness was assessed using the following ecological indicators (Magurran 1988; Neumann and Starlinger 2001; Weiner 2012): Shannon-Wiener index of richness (Eq. 1), Shannon evenness (Eq. 2), and Simpson index of dominance (Eq. 3).

$H=-\Sigma\left(p_{i} \ln p_{i}\right)$

$S E=H / \ln N$

$C=\Sigma \mathrm{i}\left(n_{i} / N\right)^{2}$

The quantitative and qualitative similarities between the reserve and the managed forest were compared using the Sørensen index as

$S=2 N t /(N a+N b) / 100 \%$

$S=2 C /(A+B) / 100 \%$

where $\mathrm{Nt}$ is the sum of common species at both sites and $\mathrm{Na}$ and $\mathrm{Nb}$ are the number of individuals recorded at sites a and $b$, respectively. Pielou's evenness index of non- 
Fig. 1 The locality of the Tabórz Scots pine provenance in the Miłomłyn Forest District, showing the climatic macroregions in northern Poland (after Kondracki 2002)
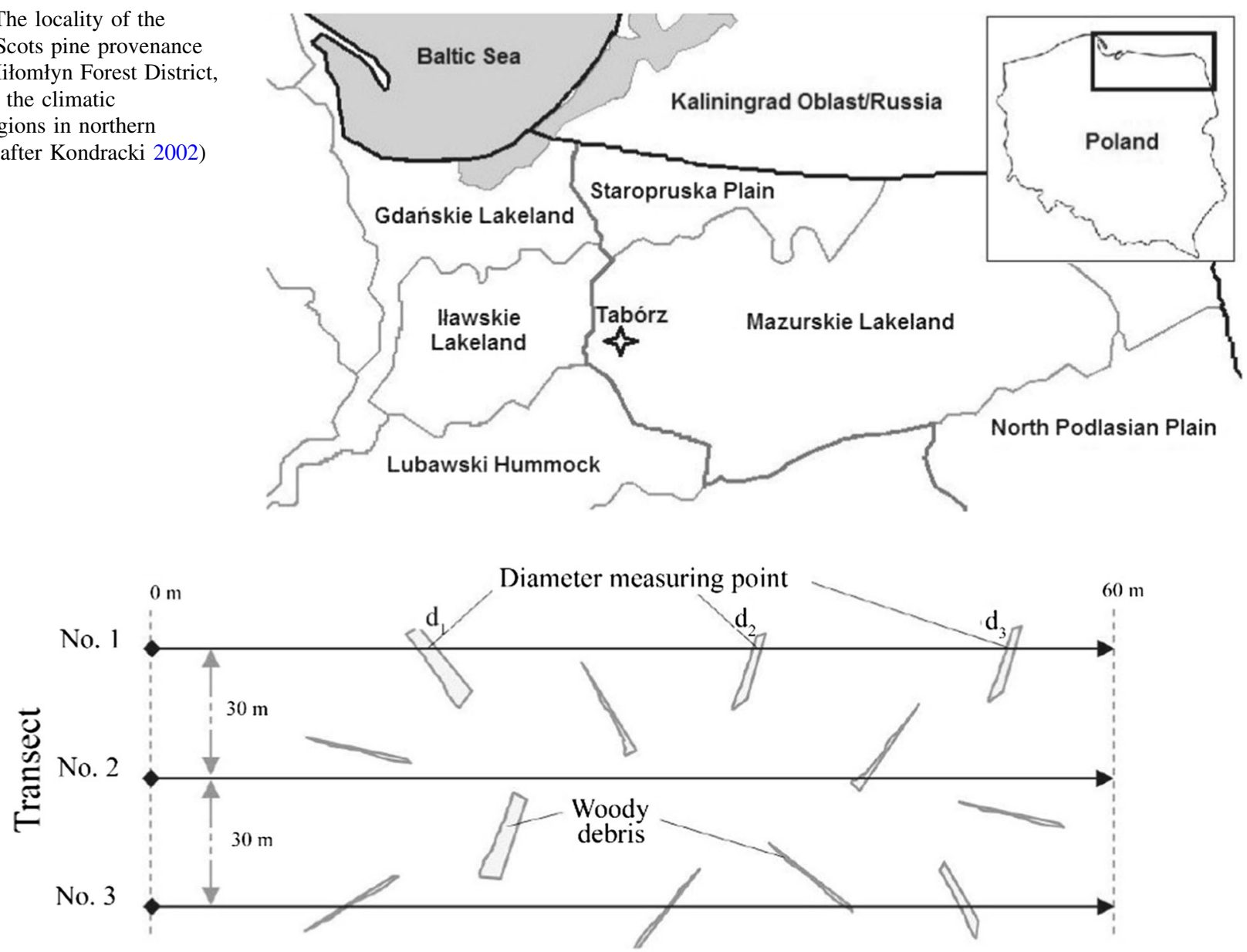

Fig. 2 Measurement method based on transects

randomness (Eq. 6) was calculated, where $P_{\mathrm{i}}$ is the relative coverage of species $i$ (or H Shannon-Wiener index) and $\mathrm{S}$ is species richness (Sørensen 1948).

$I=\left(-\Sigma P_{i} \ln P_{i}\right) / \ln S$

To assess the dispersion of CWD ( $\mathrm{m}^{3} / 0.01$ ha) with and without fruitbodies, we used the Clark-Evans index (Eq. 7) (Clark and Evans 1954; Neumann and Starlinger 2001) and adapted it to individual transects (Fig. 3). The value $\mathrm{R}=1$ means that the CWD pieces are arranged at equal distances from each other on the transect (optimal dispersion); the value $\mathrm{R}=0$ means that all pieces appear as a cluster at the same point. At $\mathrm{R}=0.5$, the pieces of CWD are randomly distributed (Fig. 3).

$\mathrm{R}=\ln \Sigma \operatorname{inr}_{i} 2 \rho$
Fig. 3 Assessment of $\mathrm{R}$ dispersion index values for CWD on the transect line (original)

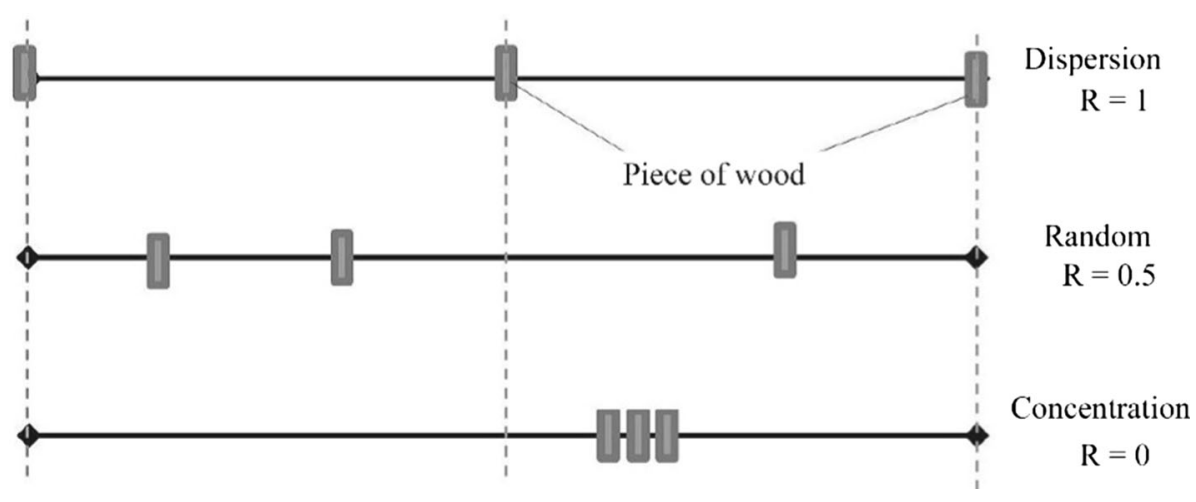




\section{Results}

\section{Abundance and thickness of deadwood resources}

At the two reserve forest sites, we recorded significantly more woody debris, exceeding that at the managed stand by more than six times. The smallest amount of woody debris was recorded for $\mathrm{P}-\mathrm{BO}$ in the managed stands $\left(9.1 \mathrm{~m}^{3} / \mathrm{ha}\right)$ and the highest amount for $\mathrm{P}-\mathrm{BO}$ in the reserve forest $\left(88.2 \mathrm{~m}^{3} / \mathrm{ha}\right)$. However, the presence of fruitbodies on the wood did not correspond with the amount of woody debris (Table 1). In the reserve, most of the woody debris samples were inhabited by many fungal species, while in the managed stands, woody debris did not yet represent a good niche for fungi. This speculation was confirmed by the number of pieces of wood per hectare (Table 1).

Overall, the number of pieces of non-colonized wood samples was greater than the number of colonized ones, probably because of the high number of thin wood samples both in the managed stand and in the reserve. The number of woody debris pieces with fruitbodies was significantly higher in the reserve than in the managed stands. The numbers of uncolonized pieces of CWD were similar in the reserve and managed forests. Despite the lack of differences in abundance, the amount of CWD was significantly greater in the reserve forest, probably due to the greater thickness (volume) of the CWD in the reserve forest.

\section{Dimensions of colonized woody debris}

The length of the CWD pieces was similar at all sampling sites. However, the thickness measured at the intersection of the transect line was significantly greater (difference $2.2 \mathrm{~cm}$ ) in the reserve forest and for colonized pieces (difference $5.5 \mathrm{~cm}$ ). The number of colonized samples was similar in the reserve and in the managed forest (Table 2). However, there were substantial differences in the fungifree sample group. Samples with and without fruitbodies in the managed stand were similar, but a difference was noted in the reserve forest, where the average thickness of the colonized wood pieces with fruitbodies was $11.7 \mathrm{~cm}$, double that of the non-colonized pieces.

In maintaining growth and inducing cell division, endogenous metabolic substances need to reach a certain threshold, or cell division will be arrested. The PE at high cell densities was relatively high, which may be because this threshold is easily reached. For the same cell density, the PE of conditioned culture and nursing culture is higher than in normal plate culture, perhaps due to the large amounts of metabolites (such as conditioning factor) in the two media promoting cell growth and division.

For the most commonly recorded fungi species, we observed a preference according to the diameter of the colonized wood (Fig. 4). This preference was reflected in the median, first, and third quartile and in the maximum and minimum diameter of the wood pieces. The post hoc test (Dunn-Bonferroni) showed that there were no

Table 1 Volume and number of fungi fruitbodies on dead wood pieces in the managed stand and the reserve in P-BOSH and P-BO sites

\begin{tabular}{|c|c|c|c|c|c|c|c|c|}
\hline \multirow[t]{2}{*}{ Site } & \multicolumn{4}{|c|}{ Volume of CWD $\left[\mathrm{m}^{3} / \mathrm{ha}\right]$} & \multicolumn{4}{|c|}{ Average number of CWD pieces per hectare } \\
\hline & $\begin{array}{l}\text { With } \\
\text { fruitbodies }\end{array}$ & $\begin{array}{l}\text { Without } \\
\text { fruitbodies }\end{array}$ & $p$ value $^{2}$ & $\begin{array}{l}\text { All } \\
\text { samples }\end{array}$ & $\begin{array}{l}\text { With } \\
\text { fruitbodies }\end{array}$ & $\begin{array}{l}\text { Without } \\
\text { fruitbodies }\end{array}$ & $p$ value $^{2}$ & $\begin{array}{l}\text { All } \\
\text { samples }\end{array}$ \\
\hline \multicolumn{9}{|l|}{ Managed } \\
\hline P-BOSH & $2.7^{\mathrm{ABb}}$ & $10.1^{\mathrm{Aa}}$ & $<0.0001$ & $12.9^{\mathrm{AB}}$ & $1720^{\mathrm{ABb}}$ & $6823^{\mathrm{Aa}}$ & $<0.0001$ & $8543^{\mathrm{A}}$ \\
\hline P-BO & $0.4^{\mathrm{Bb}}$ & $8.7^{\mathrm{Aa}}$ & $<0.0001$ & $9.1^{\mathrm{B}}$ & $265^{\mathrm{Bb}}$ & $8354^{\mathrm{Aa}}$ & $<0.0001$ & $8619^{\mathrm{A}}$ \\
\hline \multicolumn{9}{|l|}{ Reserve } \\
\hline P-BOSH & $10.4^{\mathrm{Ab}}$ & $31.0^{\mathrm{Aa}}$ & 0.000095 & $41.3^{\mathrm{AB}}$ & $2470^{\mathrm{ABb}}$ & $8878^{\mathrm{Aa}}$ & 0.00006 & $11348^{\mathrm{A}}$ \\
\hline $\mathrm{P}-\mathrm{BO}$ & $79.8^{\mathrm{Aa}}$ & $8.5^{\mathrm{Ab}}$ & 0.015793 & $88.3^{\mathrm{A}}$ & $2604^{\mathrm{Ab}}$ & $31683^{\mathrm{Aa}}$ & 0.003788 & $34,287^{\mathrm{A}}$ \\
\hline$p$ value $^{1}$ & 0,0019 & 0,9331 & - & 0.0047 & 0.0027 & 0.9235 & - & 0.8437 \\
\hline $\begin{array}{r}\text { Managed } \\
\text { average }\end{array}$ & $1.5^{\mathrm{Bb}}$ & $9.4^{\mathrm{Aa}}$ & $<0.0001$ & $10.94^{\mathrm{B}}$ & $992^{\mathrm{Bb}}$ & $7589^{\mathrm{Aa}}$ & $<0.0001$ & $8581^{\mathrm{A}}$ \\
\hline Reserve average & $45.1^{\mathrm{Aa}}$ & $19.8^{\mathrm{Ab}}$ & 0.0007 & $64.85^{\mathrm{A}}$ & $2537^{\mathrm{Ab}}$ & $20280^{\mathrm{Aa}}$ & 0.01 & $22,817^{\mathrm{A}}$ \\
\hline$p$ value $^{2}$ & 0,0006 & 0,8045 & - & 0.0006 & 0.0008 & 0.7128 & - & 0.4582 \\
\hline All areas & $23.3^{\mathrm{a}}$ & $14.6^{\mathrm{b}}$ & 0.0007 & 37.89 & $1765^{\mathrm{b}}$ & $13935^{\mathrm{a}}$ & 0.3144 & 15,700 \\
\hline
\end{tabular}

CWD coarse woody debris

The same capital letter in columns and the same lowercase letter in rows indicate that there is no significant difference at $p \leq 0.05$

${ }^{1}$ Kruskal-Wallis test

${ }^{2}$ Mann-Whitney test 
Table 2 Comparison of diameter and length of colonized and non-colonized woody debris in the analyzed sites

\begin{tabular}{|c|c|c|c|c|c|c|c|c|}
\hline \multirow[t]{2}{*}{ Site } & \multicolumn{4}{|l|}{ Diameter $(\mathrm{cm})$} & \multicolumn{4}{|l|}{ Length (m) } \\
\hline & With fruitbodies & Without fruitbodies & $p$ value $^{2}$ & Average & With fruitbodies & Without fruitbodies & $p$ value $^{2}$ & Average \\
\hline \multicolumn{9}{|l|}{ Managed stand } \\
\hline P-BOSH & $5.4^{\mathrm{Aa}}$ & $4.5^{\mathrm{Aa}}$ & 0.58142 & $4.7^{\mathrm{AB}}$ & $0.97^{\mathrm{Aa}}$ & $1.33^{\mathrm{Aa}}$ & 0.75135 & $1.3^{\mathrm{A}}$ \\
\hline P-BO & $4.1^{\mathrm{Aa}}$ & $4.2^{\mathrm{Aa}}$ & 0.13519 & $4.2^{\mathrm{B}}$ & $1.17^{\mathrm{Aa}}$ & $1.35^{\mathrm{Aa}}$ & 0.400953 & $1.3^{\mathrm{A}}$ \\
\hline \multicolumn{9}{|l|}{ Reserve forest } \\
\hline P-BOSH & $6.6^{\mathrm{Aa}}$ & $6.4^{\mathrm{Aa}}$ & 0.84491 & $6.5^{\mathrm{AB}}$ & $2.24^{\mathrm{Aa}}$ & $1.23^{\mathrm{Aa}}$ & 0.746086 & $1.5^{\mathrm{A}}$ \\
\hline P-BO & $15.8^{\mathrm{Aa}}$ & $4.8^{\mathrm{Ab}}$ & 0.00167 & $8.3^{\mathrm{A}}$ & $2.44^{\mathrm{Aa}}$ & $1.08^{\mathrm{Aa}}$ & 0.061872 & $1.5^{\mathrm{A}}$ \\
\hline$p$ value $^{1}$ & 0.0898 & 0.0631 & - & 0.0047 & 0.5611 & 0.3726 & - & 0.8736 \\
\hline Managed stand & $5.1^{\mathrm{Aa}}$ & $4.3^{\mathrm{Ba}}$ & 0.09266 & $4.4^{\mathrm{B}}$ & $1.01^{\mathrm{Aa}}$ & $1.34^{\mathrm{Aa}}$ & 0,549997 & $1.3^{\mathrm{A}}$ \\
\hline Reserve forest & $11.7^{\mathrm{Aa}}$ & $5.7^{\mathrm{Ab}}$ & 0.01539 & $7.3^{\mathrm{A}}$ & $2.35^{\mathrm{Aa}}$ & $1.16^{\mathrm{Aa}}$ & 0,097567 & $1.5^{\mathrm{A}}$ \\
\hline$p$ value $^{2}$ & 0.1699 & 0.0073 & - & 0.0006 & 0.2323 & 0.1180 & & 0.4834 \\
\hline All & $10.0^{\mathrm{a}}$ & $5.0^{\mathrm{b}}$ & 0.00075 & 6.0 & $2.0^{\mathrm{a}}$ & $1.25^{\mathrm{a}}$ & 0.314366 & 1.40 \\
\hline
\end{tabular}

The same capital letter in columns and the same lowercase letter in rows indicate that there is no significant difference at $p \leq 0.05$

${ }^{1}$ Kruskal-Wallis test

${ }^{2}$ Mann-Whitney test

Fig. 4 Mean diameter $(\mathrm{cm})$ of wood samples colonized by the most frequent fungi. The same capital letter indicates no significant difference at $p \leq 0.05 ; p$ value $=0.000082$ (Kruskal-Wallis test). WF wood without fruitbodies, numbers correspond to taxa numerated in Table 4

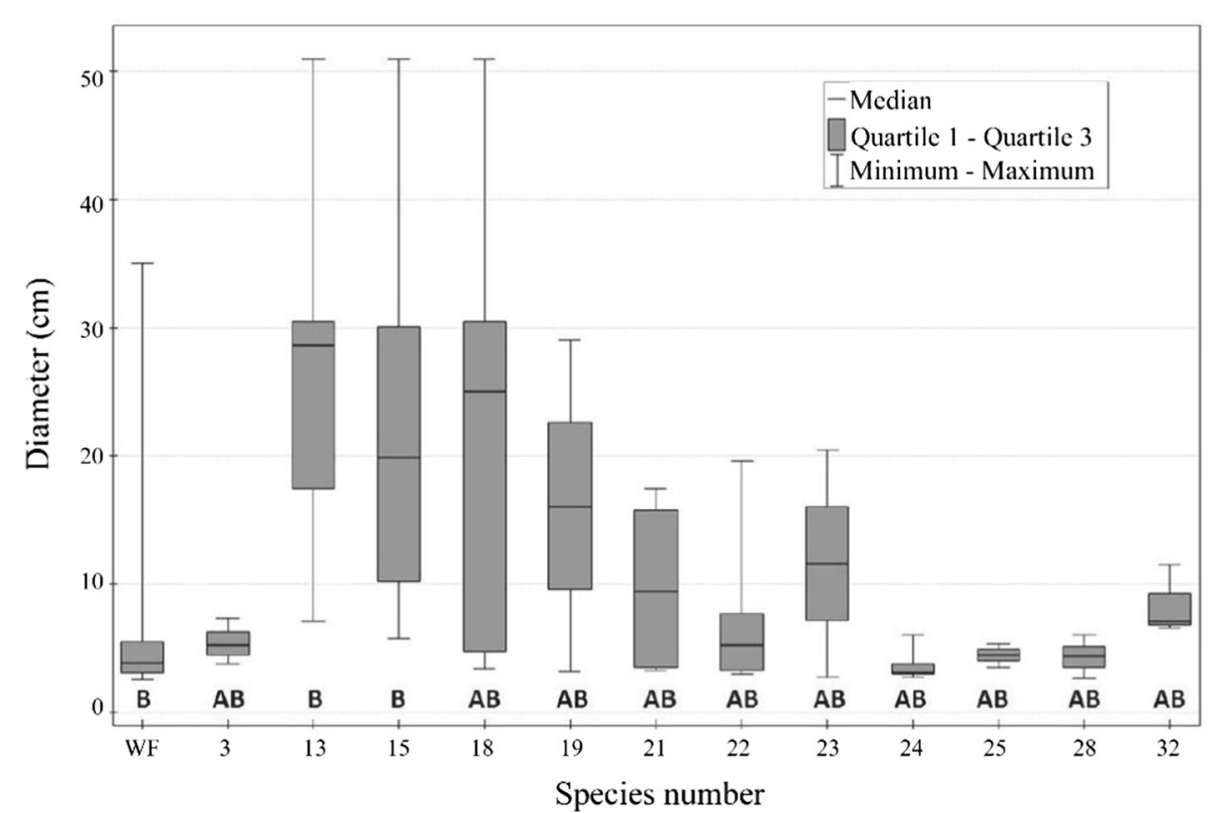

significant differences in the diameter of the colonized wood between fungal species, but there was a difference between the pieces without fruitbodies and the diameter of the wood colonized by $F$. fomentarius (L.) and $F$. pinicola (Sw.).

The dispersion index (R) for CWD oscillated around 0.5 , indicating a random distribution (Table 3). When analyzed for colonized wood only, the dispersion index varied more widely. The lowest value, indicating aggregation, was recorded in the reserve in the P-BOSH habitat. The distribution of dead wood with fruitbodies (Fig. 5) showed, however, that the groups of fungi gathered around the thickest wood pieces.

Both in the managed stands and in the reserve forest, wood pieces with a diameter of up to $10 \mathrm{~cm}$ were most common. A high amount of dead wood in the reserve seems to be a result of the dispersion of thick samples. The greater number of fruiting fungal specimens was associated with relatively thick woody debris pieces. However, not all of the thicker samples were colonized, possibly related to the early stages of wood decay and the short period of our observations. In the P-BO compartment in the reserve, the maximum number of wood pieces with fruiting bodies per 
Table 3 Values of the ClarkEvans dispersion index $\mathrm{R}$ for coarse wood debris (CWD) in the assessed areas

\begin{tabular}{llllll}
\hline Site type & \multicolumn{2}{l}{ Reserve } & & \multicolumn{2}{l}{ Managed stand } \\
\cline { 2 - 3 } & CWD & CWD with fungus & & CWD & CWD with fungus \\
\hline Deciduous forest (P-BOSH) & 0.49 & 0.35 & 0.54 & 0.66 \\
Mixed deciduous forest (P-BO) & 0.59 & 0.53 & 0.52 & 0.46 \\
Average & 0.54 & 0.44 & & 0.53 & 0.56 \\
\hline
\end{tabular}

transect meter was six. In managed stands, a maximum of two specimens per transect meter were recorded. Considering the distribution index (Table 3) and the CWD cell share of the transects (Fig. 5a, b), the reserve and the managed stand had similar distributions of dead wood and both were random $(\mathrm{R}=0.5)$. More $\mathrm{CWD}$ pieces, and more cells containing CWD at volume densities $>1 \mathrm{~m}^{3} / 0.01$ ha, were recorded in the reserve than in the managed stand (Fig. 5b). The presence of high-density cells may have affected the Clark-Evans distribution index for CWD with fruiting bodies (Table 3).

In the reserve, pieces of CWD with fruiting bodies were clustered, especially in the P-BOSH compartment, where the Clark-Evans index was 0.35. In the managed stand for the same compartment, this index was 0.66 , indicating that CWD was more dispersed. No cell containing CWD pieces with a volume density of more than $10 \mathrm{~m}^{3} / 0.01$ ha was found in the stands, and half of the cells contained a CWD volume density of more than $1 \mathrm{~m}^{3} / 0.01$ ha compared to the reserve.

\section{Diversity of fungal communities}

Overall, we identified 32 taxa of Basidiomycota and Ascomycota. The numbers of specimens (50) and species (25) on both sites were greater in the reserve compared to the managed stand (15 and 12, respectively; Table 4). The greatest number of species (19) was found in the P-BO site in the reserve. The most common taxa were $F$. pinicola, $F$. fomentarius, Trametes versicolor, and Phlebia radiata, The diversity of fungal communities varied by forest type and site type (Table 5). In the reserve, Simpson's dominance was greater at the $\mathrm{P}-\mathrm{BO}$ than at the $\mathrm{P}-\mathrm{BOSH}$ site, whereas in the managed forest at the P-BOSH site, this value was greater. This confirms the value of the Sørensen quality index, which was 0.24 for the reserve and 1.0 for the managed forest stand. The highest dominance index was calculated for the P-BO site.

In the reserve, Pielou evenness showed a uniform distribution of eudominants between only three species $(F$. fomentarius, $F$. pinicola, and $S$. hirsutum). Diversity in the reserve was greatest at the $\mathrm{P}-\mathrm{BO}$ site, while in the managed stand, higher values, although not significant, were recorded at the P-BOSH site.

\section{Discussion}

Site conditions are important factors determining the amount of woody debris and, consequently, forest biodiversity (Sturtevant et al. 1997; Boddy and HeilmannClausen 2008; Herrmann and Bauhus 2012; Bujoczek et al. 2016). In our study, the stock of woody debris was more strongly associated with the management style (harvested stand or reserve) than with the habitat type. Other studies (Walankiewicz 2002; Pawicka and Woziwoda 2011; Gossner et al. 2013; Holeksa et al. 2014) confirm the value of protected forest areas in terms of deadwood resources. Our knowledge of the amount and size of woody debris in a given habitat remains incomplete, and this subject needs further research. Nearly all humus (90\%) is produced by fungal activities, while $10 \%$ of the humus result from the activities of bacteria and other soil organisms, depending on the wood species, wood volume, and age (Franklin et al. 1987; Lofroth 1998; Holeksa et al. 2008). Sippola and Renvall (1999) reported that in managed forests in northern Finland, wood residues left on the forest floor over a period of 40 years were successively colonized by only $40-50 \%$ of the species present in unmanaged forests. Many taxa preferably colonize small woody debris; in the Białowieża National Park, 84 taxa colonized small branches, including 43 species typical for such substrate (Skirgiełło 1998).

Our results indicate that living and dead wood in managed stands has an important positive impact on the amount of coarse woody debris on the forest floor. In the managed forest stand, the amount of dead wood was lower than in the reserve, albeit relatively high compared to the other managed stands in Poland (Bujoczek et al. 2016). In the reserve, the distribution of CWD was more aggregated and average diameter was greater. This seemed to be a result of the forestry practices, which either focused on the collection of timber (by cutting, thinning, harvesting) and the removal of woody debris from the stand or on the abandonment of CWD (Aakala 2010; Dunn and Bailey 2012). Woody debris is naturally colonized by a variety of

Fig. 5 a Dispersion of dead wood and number of fruitbodies on transect sections (cells). b Volume ( $\left.\mathrm{m}^{3} / 0.01 \mathrm{ha}\right)$, diameter, and number of CWD on transects section (cell). CWD coarse woody debris 
(a)

\begin{tabular}{|c|c|c|c|}
\hline \multicolumn{2}{|c|}{ Managed stand } & \multicolumn{2}{|c|}{ Reserve forest } \\
\hline$\overline{F B F}$ & FMBF & $\overline{F B F}$ & FMBF \\
\hline Transect & Transect & Transect & Transe \\
\hline
\end{tabular}

$0 \mathrm{~m}$

\begin{tabular}{l|l|l|l|l|l|l|l|l|l|l|l|}
1 & 2 & 3 & 1 & 2 & 3 & 1 & 2 & 3 & 1 & 2 & 3 \\
\hline
\end{tabular}

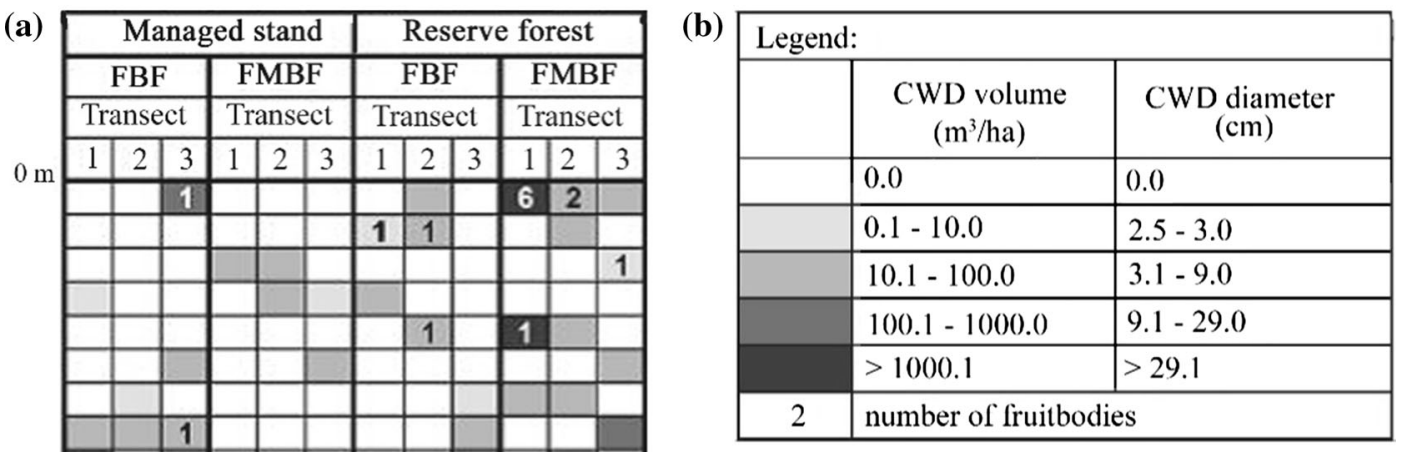

(b)

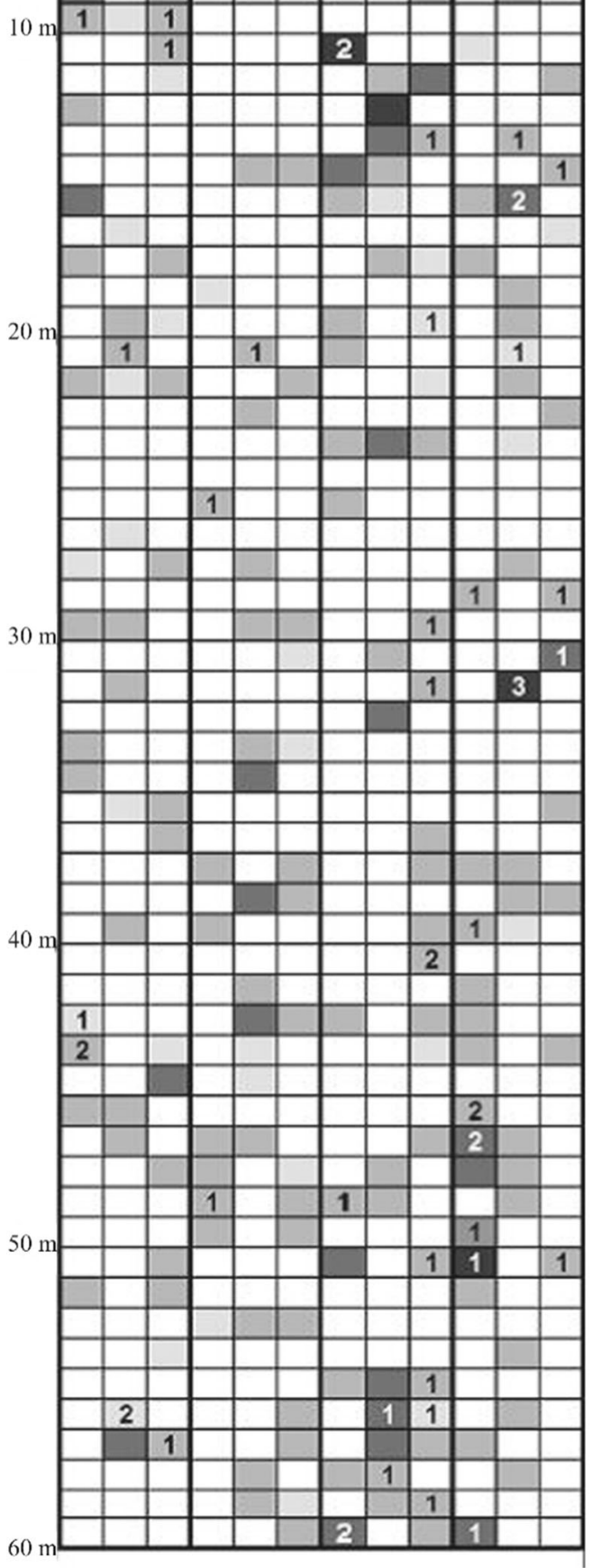


Table 4 Fungi with fruitbodies on deadwood and wood diameter and length on the transect

\begin{tabular}{|c|c|c|c|c|c|c|c|}
\hline \multirow[t]{3}{*}{ No. } & \multirow[t]{3}{*}{ Taxon } & \multicolumn{4}{|l|}{ Fungi } & \multicolumn{2}{|c|}{ Dead wood } \\
\hline & & \multicolumn{2}{|l|}{ Reserve } & \multicolumn{2}{|c|}{ Managed stand } & \multirow{2}{*}{$\begin{array}{l}\text { Diameter } \\
(\mathrm{cm})\end{array}$} & \multirow{2}{*}{$\begin{array}{l}\text { Length } \\
\text { (m) }\end{array}$} \\
\hline & & P-BOSH & P-BO & P-BOSH & $\mathrm{P}-\mathrm{BO}$ & & \\
\hline
\end{tabular}

\section{Division: Basidiomycota}

Class: Agaricomycetes

Order: Agaricales

1.

2.

3.

4.

5.

6.

7.

8.

9.

Order: Polyporales

10.

11.

12.

13.

14.

15.

16.

17.

18.

19.

Order: Auriculariales
20.
21.
Exidia nigricans (With.) P. Roberts
Exidia glandulosa (Bull.) Fr.

Order: Russulales

22.

Order: Gloeophyllales

23.

Order: Meruliaceaes

24.

Order: Hymenochaetales

25.

Basidioradulum radula (Fr.) Nobles

Mycena galericulata (Scop.) Gray

Cyathus striatus (Huds.) Willd

Clitocybe gibba (Pers.) P.Kumm.

Lycoperdon pyriforme Schaeff.

Piptoporus betulinus (Bull.) P.Karst.

Postia stiptica (Pers.) Jülich

Fomitopsis pinicola (Sw.) P.Karst.

Bjerkandera adusta (Willd.) P.Karst.

Trametes suaveolens (L.) Fr.

Trametes versicolor (L.) Lloyd

Trametes hirsuta (Wulfen) Lloyd

Stereum hirsutum (Willd.) Pers.

Phlebia radiata $\mathrm{Fr}$.
Crepidotus variabilis (Pers.) P.Kumm.

Pluteus atricapillus (Schaeff.) P.Kumm.

Oudemansiella mucida (Schrad.) Pat.

Marasmius alliaceus (Jacq.) Earle ex A.W. Wilson

Kuehneromyces mutabilis (Schaeff.) Singer \& A.H.Sm.

Climacocystis borealis (Fr.) Kotl. \& Pouzar

Fomes fomentarius (L.) Fr.

Ganoderma adspersum (Schulzer) Donk

Gloeophyllum odoratum (Wulfen) Imazeki

Class: Dacrymycetes

Order: Dacrymycetales

26.

Calocera cornea (Batsch) Fr.

Division: Ascomycota

Class: Sordariomycetes

Order: Xylariales

$$
27 .
$$

28.

29.

Order: Hypocreales

30.

Diatrype disciformis (Hoffm.) Fr.

Xylaria polymorpha (Pers.) Grev.

Kretzschmaria deusta (Hoffm.) P.M.D. Martin

Hypocrea rufa Pers.

Nectria cinnabarina (Tode) Fr.
1

3

1

2.5

7.0

5.4

2.7

51.0

14.0

1

7.8

4.5

51.0

1

1

7.0

70.0

2.5

26.9

51.0

22.8

1

22.8
3.5

14.0

22.9

16.1

3

8.0

15.2

1.0

1

6

2

6.8

2

11.6

1

3

3.7

0.7

2

4.4

1.1

2

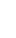

2

.7


Table 4 continued

\begin{tabular}{|c|c|c|c|c|c|c|c|}
\hline \multirow[t]{3}{*}{ No. } & \multirow[t]{3}{*}{ Taxon } & \multicolumn{4}{|l|}{ Fungi } & \multicolumn{2}{|c|}{ Dead wood } \\
\hline & & \multicolumn{2}{|l|}{ Reserve } & \multicolumn{2}{|c|}{ Managed stand } & \multirow{2}{*}{$\begin{array}{l}\text { Diameter } \\
(\mathrm{cm})\end{array}$} & \multirow{2}{*}{$\begin{array}{l}\text { Lengtl } \\
\text { (m) }\end{array}$} \\
\hline & & $\mathrm{P}-\mathrm{BOSH}$ & $\mathrm{P}-\mathrm{BO}$ & P-BOSH & $\mathrm{P}-\mathrm{BO}$ & & \\
\hline \multicolumn{8}{|c|}{ Class: Leotiomycetes } \\
\hline \multicolumn{8}{|l|}{ Order: Helotiales } \\
\hline 32. & Bisporella citrina (Batsch) Korf \& S.E.Carp. & & 1 & 2 & & 8.3 & 1.1 \\
\hline Specimens total & & 20 & 30 & 12 & 3 & & \\
\hline Number of species & & 9 & 19 & 9 & 3 & & \\
\hline Species total & & \multicolumn{2}{|l|}{25} & \multicolumn{2}{|c|}{12} & & \\
\hline
\end{tabular}

Table 5 Values of some ecological indices for the fungal communities in the Miłomłyn Forest District

\begin{tabular}{llllll}
\hline Indices & \multicolumn{2}{l}{ Reserve } & & \multicolumn{2}{l}{ Managed forest } \\
\cline { 2 - 3 } \cline { 6 - 7 } \cline { 6 - 7 } & P-BOSH & P-BO & & P-BOSH & P-BO \\
\hline Simpson dominance index C & 0.1791 & 0.0725 & & 0.1389 & 0.3333 \\
Simpson diversity index DI & 0.8201 & 0.9275 & & 0.8611 & 0.6667 \\
Shannon diversity index SH & 1.9470 & 2.7937 & & 2.0947 & 1.0986 \\
Sørensen quality index S & 0.24 & 1 & & \\
Pielou evenness index I & 0.88 & 0.94 & 0.95 & 1 \\
\hline
\end{tabular}

$P$-BOSH deciduous forest, $P$ - $B O$ mixed deciduous forest

different fungi species; the abundance of these species is a direct result of natural or artificial disturbances (Stokland et al. 2012; Brazee et al. 2014).

We identified a total of 32 fungal species on dead wood, but only five species were present in both forest types. Woody debris at the P-BO site was colonized by 22 species, whereas at the P-BOSH site, we detected 18 species. This low fungal community richness corroborates the results reported by Stokland and Larsson (2011). Some fungi, e.g. Crepidotus variabilis and Cyathus striatus, inhabited relatively small pieces of wood, while others were mainly found on larger pieces (stumps, logs), e.g., Postia stiptica and Ganoderma adspersum (sporadic) or $F$. fomentarius and $F$. pinicola (frequent). A relationship between CWD size and fungal community diversity was also described by Heilmann-Clausen and Christensen (2004) and Brazee et al. (2014). Some fungi were recorded infrequently and were only present in one habitat in the reserve forest, e.g., Oudemansiella mucida or Kretzschmaria deusta.
Fungal communities found in the managed stand and the reserve varied qualitatively, but supported similar dominating species, including $F$. fomentarius, $F$. pinicola, $T$. versicolor, and $B$. citrina. These species could not reliably be used to differentiate communities because of their wide ecological tolerance spectrum (Skirgiełło 1998). Within the transects in the reserve, the similarity was low in terms of species richness, but high in terms of the number of specimens, possibly due to the rich community at the P-BO site. In contrast, the communities in both habitats in the managed stand were dissimilar. A decreased diversity of fungi in managed stands was also described by Stokland and Larsson (2011).

The management of old Scots pine stands must be based on their ecological properties in different trophic and climatic regimes and on the local forest cultivation policies. In Tabórz reserve, where no management activities were performed for many years, the fungal community richness was surprisingly relatively low, with poor species richness compared to that of other national parks or reserves in Poland. Skirgiełło (1998), for example, reported 83 single, dispersed saprotrophs in Białowieża National Park, albeit on a greater area $\left(1000 \mathrm{~m}^{2}\right)$, and Nowińska et al. (2009) reported 25 species in two oak-hornbeam reserves. In our research, the amount of woody debris and the fungal richness (12 species) were lower in the managed stand than in the reserve ( 28 species), but higher than in other managed state forests. Kwaśna et al. (2016) described 21 Basidiomycota species colonizing 100-year-old Scots pine CWD in the Torzym Forest District.

The Clark-Evans index of dispersion not only depicts the distribution of CWD in a stand, but can also quantify the degree of tree diversity (Neumann 2001). Areas with greater deadwood resources may be associated with local tree extraction from tree stands and resulting changes in 
tree structure. This method should be subjected to wider testing.

Fungi, as a specific functional group, feed on dead wood as a food base and seem to be a good target group to create diversity and abundance models (Belaoussoff et al. 2003). Simpson's index is suitable for this group because of its wider amplitude and greater discrimination (Maria and Sridhar 2002; Feest 2006). We confirmed that forest reserves harbor a greater diversity of wood-colonizing fungi than do managed stands. In addition, the tendency to colonize substrate does not depend on the size of the CWD, but rather on the arrangement of the woody debris on the forest floor and the local fungal species populations. The results of our study lead us to infer that the transfer of fungal species from reserves to managed forests is relatively poor, and that such species have a low ecological plasticity in younger managed forests. The relatively high volume of woody debris as well as the diversity of fungi in the harvested stands testify to the value of the ecological approach to forest management in old Scots pine stands.

Acknowledgements We thank the staff of the Miłomłyn Forest District and the Regional Directorate of Environmental Protection in Olsztyn for providing access to the areas and useful information about them. The study was part of the Engineering Thesis of Mrs Agata Sotnik at the Faculty of Forestry and Forest Ecology, University of Warmia and Mazury in Olsztyn, under the supervision of Z. Sierota. The authors would also like to thank the anonymous reviewers for their valuable comments and suggestions.

Author's contributions ZS and SP originally formulated the idea, ZS, AS and SP developed methodology, AS conducted fieldwork, all authors generated and analyzed the data, SP collaborated in imaging analysis, SP and MD performed statistical analyses, all authors wrote parts of the manuscript and provided editorial advice.

\section{Compliance with ethical standards}

Ethical approval All procedures involving human participants were in accordance with the ethical standards of the institutional and/or national research committee and with the 1964 Helsinki declaration and its later amendments or comparable ethical standards.

Open Access This article is distributed under the terms of the Creative Commons Attribution 4.0 International License (http://crea tivecommons.org/licenses/by/4.0/), which permits unrestricted use, distribution, and reproduction in any medium, provided you give appropriate credit to the original author(s) and the source, provide a link to the Creative Commons license, and indicate if changes were made.

\section{References}

Aakala T (2010) Coarse woody debris in late-successional Picea abies forests in northern Europe: variability in quantities and models of decay class dynamics. For Ecol Manag 260:770-779

Belaoussoff S, Kevan PG, Murphy S, Swanton C (2003) Assessing tillage disturbance on assemblages of ground beetles
(Coleoptera: Carabidae) by using a range of ecological indices. Biodivers Conserv 12:851-882

Bobiec A (2002) Living stands and dead wood in the Białowieża Forest: suggestions for restoration management. For Ecol Manag 165:125-140. https://doi.org/10.1016/S0378-1127(01)00655-7

Boddy L, Heilmann-Clausen J (2008) Basidiomycete community development in temperate angiosperm wood. In: Boddy L, Frankland JC, van West P (eds) Ecology of saprotrophic basidiomycetes. Elsevier, Amsterdam, pp 211-237

Böhl J, Brändli U-B (2007) Deadwood volume assessment in the third Swiss National Forest Inventory: methods and first results. Eur J For Res 126:449-457

Brazee NJ, Lindner DL, D'Amato AW, Fraver S, Forrester JA, Mladenoff DJ (2014) Disturbance and diversity of woodinhabiting fungi: effects of canopy gaps and downed woody debris. Biodivers Conserv 23:2155-2172

Breitenbach J, Kränzlin F (1984) Pilze der Schweiz. Beitrag zur Kenntnis der Pilzflora der Schweiz. Band 1. Ascomyceten. Verl Mykologia, Luzern

Breitenbach J, Kränzlin F (1986) Pilze der Schweiz. Beitrag zur Kenntnis der Pilzflora der Schweiz. Band 2. Heterobasidiomycetes, Aphylloporales, Gastromycetes. Verl Mykologia, Luzern

Breitenbach J, Kränzlin F (1991) Pilze der Schweiz. Beitrag zur Kenntnis der Pilzflora der Schweiz. Band 3. Röhrlinge und Blätterpilze. Teil 1. Strobilomycetaceae und Boletaceae, Paxillaceae, Gomphidiaceae, Hygrophoraceae, Tricholomataceae, Polyporaceae (lamellige). Ver Mykologia, Luzern

Breitenbach J, Kränzlin F (1995) Pilze der Schweiz. Beitrag zur Kenntnis der Pilzflora der Schweiz. Band 4. Blätterpilze. Teil 2. Entolomataceae, Pluteaceae, Amanitaceae, Agaricaceae, Coprinaceae, Bolbitiaceae, Strophariaceae. Verl Mykologia, Luzern

Breitenbach J, Kränzlin F (2000) Pilze der Schweiz. Beitrag zur Kenntnis der Pilzflora der Schweiz. Band 5. Blätterpilze. Teil 3. Cortinariaceae. Verl Mykologia, Luzern

Bujoczek L, Zięba S, Banaś J (2016) Effect of site conditions and site index for the dominant tree species on the amount of deadwood in managed forests/Ocena zasobów martwego drewna w lasach gospodarczych z uwzględnieniem typów siedliskowych lasu oraz bonitacji gatunku panującego/in Polish with English summary. Sylwan 160(4):320-327

Clark PJ, Evans FC (1954) Distance to nearest neighbor as a measure of spatial relationships in populations. Ecology 35(4):445-453

Dudley N, Vallauri D (2004) Deadwood, living forests. The importance of veteran trees and deadwood to biodiversity. WWF Brochure, Gland, p 16

Dunn CJ, Bailey JD (2012) Temporal dynamics and decay of coarse wood in early seral habitats of dry-mixed conifer forests in Oregon's Eastern Cascades. For Ecol Manag 276:71-81

Feest A (2006) Establishing baseline indices for the quality of the biodiversity of restored habitats using a standardized sampling process. Restor Ecol 14(1):112-122

Forest Act (1991) http://www.fao.org/faolex/results/details/en/ ?details=LEX-FAOC060026

Franklin JF, Shugart HH, Harmon ME (1987) Tree death as an ecological process. BioScience 37:550-556

Gossner MM, Lachat T, Brunet J, Isacsson G, Bouget C, Brustel H, Brandl R, Weisser WW, Müller J (2013) Current near-to-nature forest management effects on functional trait composition of saproxylic beetles in beech forests. Conserv Biol 27(3):605-610

Harmon ME, Franklin JF, Swanson FJ, Sollins P, Gregory SV, Lattin JD, Anderson NH, Cline SP, Aumen NG, Sedell JR, Lienkaemper GW, Cromack K Jr, Cummins KW (1986) Ecology of coarse woody debris in temperate ecosystems. Adv Ecol Res 15:133-302 
Heilmann-Clausen J, Christensen M (2004) Does size matter? On the importance of various dead wood fractions for fungal diversity in Danish beech forests. For Ecol Manag 201:105-117

Herrmann S, Bauhus J (2012) Effects of moisture, temperature and decomposition stage of respirational carbon loss from coarse wood debris (CWD) of important European tree species. Scand J For Res 28:346-357

Holeksa J, Zielonka T, Zywiec M (2008) Modelling the decay of coarse woody debris in a subalpine Norway spruce forest of the West Carpathians, Poland. Can J For Res 38:415-428

Holeksa J, Żywiec M, Kurek P (2014) Amount of dead wood in managed forests in connection with demands of nature protection in Natura 2000 areas-from static to dynamic approach (in Polish with English summary). In: Proceedings of the center for nature and forestry Education, vol 16. 41(4)

Kondracki J (2002) Regional geography of Poland/Geografia regionalna Polski/In Polish. Wyd. Nauk. PWN, Warszawa

Kränzlin F (2005) Pilze der Schweiz. Beitrag zur Kenntnis der Pilzflora der Schweiz. Band 5. Russulaceae. Verlag Mykologia, Luzern

Kruk H, Kornatowska B (2014) Sustainable forest management in Poland-theory and practice. Folia For Pol ser A 56(1):45-55

Kwaśna H, Mazur A, Łabędzki A, Kuźmiński R, Łakomy P (2016) Communities of fungi in decomposed wood of oak and pine. Leś Pr Bad/For Res Pap 77(3):261-275. https://doi.org/10.1515/frp2016-0028

Lofroth E (1998) The dead wood cycle. In: Voller J, Harrison S (eds) Conservation biology principles for forested landscapes. UBC Press, Vancouver, B.C., pp 185-214

Ludwig E (2007) Pilzkompendium. T. 2: Abbildungen. Die größeren Gattungen der Agaricales mit farbigem Sporenpulver (ausgenommen Cortinariaceae). Fungicon Verlag, Berlin

Magurran AE (1988) Ecological diversity and its measurement. Princeton Univ Press, Princeton

Maria GL, Sridhar KR (2002) Richness and diversity of filamentous fungi on woody litter of mangroves along the west coast of India. Curr Sci 83(12):1573-1580

Marshall PL, Davis G, LeMay VM (2000) Using line intersect sampling for coarse woody debris. Res Sec, Van For Reg., B.C. Min For, Nanaimo, B.C. Tec. Rep. TR-003

Motta R, Berretti R, Lingua E, Piussi P (2006) Coarse woody debris, forest structure and regeneration in the Valbona Forest Reserve, Paneveggio, Italian Alps. For Ecol Manag 235:155-163

Nemec AFL, Davis G (2002) Efficiency of six line intersect sampling designs for estimating volume and density of coarse woody debris. For Res Tech Rep TR-021. British Columbia For. Serv. Available: https://www.for.gov.bc.ca/rco/research/cwd/tr021.pdf

Neumann M (2001) The significance of different indices for stand structure and diversity in forests. For Ecol Manag 145(1):91-106

Neumann M, Starlinger F (2001) The significance of different indices for stand structure and diversity in forests. For Ecol
Manag 145(1-2):91-106. https://doi.org/10.1016/S0378-1127 (00)00577-6

Nowińska R, Urbański P, Szewczyk W (2009) Species diversity of plants and fungi on logs and fallen tree of different species in oak-hornbean forests. Botanika Steciana 13:109-124

Pasierbek T, Holeksa J, Wilczek Z, Zywiec M (2007) Why the amount of dead wood in Polish forest reserves is so small? Nat Conserv 64:65-71

Pawicka K, Woziwoda B (2011) Balance of dead wood in the 'Polesie Konstantynowskie' nature reserve (central Poland)/Bilans martwego drewna w rezerwacie, Polesie Konstatntynowskie"/in Polish with English summary. Sylwan 155(12):851-858

Polityka Lesna Państwa (1997) Forest policy in Poland. Min. Envir. Prot., Nat. Res. For., Warszawa, p 27

PQStat software ver. 1.6.4. Available: www.PQStat.com

Sippola AL, Renvall P (1999) Wood-decomposing fungi and seedtree cutting: a 40-year perspective. For Ecol Manag 115(2-3):183-201

Skirgiełło A (1998) Macromycetes of oak-hornbean forests in the Białowieża National Park-monitoring studies. Acta Mycol 33(2):171-189

Skwarek K, Bijak SZ (2015) Resources of dead wood in the municipal forests in Warsaw. Leś $\operatorname{Pr} \mathrm{Bad} / \mathrm{For}$ Res Pap 76(4):322-330. https://doi.org/10.1515/frp-2015-0031

Sørensen T (1948) A method of establishing groups of equal amplitude in plant sociology base on similarity of species and its application to analyses of vegetation on Danish commons. Biol Skr 5:1-34

Stokland JN, Larsson N (2011) Legacies from natural forest dynamics: different effects of forest management on woodinhabiting fungi in pine and spruce forests. For Ecol Manag 261:1707-1721

Stokland JN, Siitonen J, Jonsson BG (2012) Biodiversity in dead wood. Cambrifge Univ Press, Cambridge, p 509

Sturtevant BR, Bissonette JA, Long JN, Roberts DW (1997) Coarse woody debris as a function of age, stand structure, and disturbance in Boreal Newfoundland. Ecol Appl 7(2):702-712

Szewczyk J, Szwagrzyk J (1996) Tree regeneration on rotten wood and on soil in old-growth stand. Vegetatio 122:37-46

Van Wagner CE (1968) The line intersect method in forest fuel sampling. For Sci 14(1):20-26

Walankiewicz W (2002) The number and composition of snags in the pine-spruce stands of the Bialowieza National Park, Poland. USDA For Serv Gen Tech Rep PSW-GTR-181 489 - 500. Available: https://www.researchgate.net/publication/237464426

Weiner J (2012) Life and biosphere evolution/Życie i ewolucja biosfery. Podręcznik ekologii ogólnej/in Polish. Wyd.2. Wyd. Nauk. PWN, Warszawa 